Bhatter College Journal of Multidisciplinary Studies

Approved by the UGC (Serial No. 629, Subjects: Education, Broad category: Social Sciences)

ISSN 2249-3301, Vol. VII, Number 1, 2017

Article url: www.bcjms.bhattercollege.ac.in/v7/n1/mc-en-v7-01-02.pdf

Article DOI: 10.25274/bcjms.v7n1.mc-en-v7-01-02

\title{
Beneficiaries of Foreign Direct Investment in Organised Food Retailing in India
}

\author{
Itisha Rohatgi \\ Research Scholar,IFTM University Moradabad.Email: itisharohatgi@yahoo.co.in
}

\begin{abstract}
The organised food retail in India is fast growing. The government's decision to permit foreign direct investment in single-brand and multi-brand retail has given an impetus to it furthermore. On one hand, it is claimed that the foreign investment would be beneficial for all the stakeholders - farmers, consumers, domestic organised retailers, local traders, government and manufacturers while on the other hand few economic experts have certain apprehensions regarding the policy that it would lead to monopolistic practices, large-scale exit of small retailers, predatory pricing and rise of real estate cost. The present paper intends to examine the condition of the various stakeholders - farmers, consumers, domestic organised retailers, local traders, government and real estate sector; in the wake of introduction of foreign direct investment in the retail sector and provide suitable policy suggestions in the interests of the same.
\end{abstract}

Keywords: Foreign direct investment, multi-brand retail, organised food retail, single-brand retail, stakeholders.

JEL Code: F6, O1, Q1

\subsection{Indian Retail Sector}

The retail industry in India is segregated into organised and unorganised sector. Organised retailing refers to the trading activities carried out by licensed retailers, that is, those who are registered for sales tax, income tax, etc. These include the corporate-backed supermarkets, hypermarkets and retail chains, and also the privately owned large retail businesses. Unorganised retailing, on the other hand, refers to the traditional low-cost retailing format, dominated by large number of small retailers and traders consisting of local kirana shops, owner manned general stores, chemists, footwear shops, paan or beedi shops, hand-cart vendors, pavement vendors etc. ${ }^{6}$ (Corporate Catalyst India Pvt. Ltd. 2016)

Indian retailing industry is customarily dominant with these small and medium unorganised enterprises whereas the organised retail sector is still at an embryonic stage. The report of ASSOCHAM India (Associated Chambers of Commerce and Industry of India) states that the organised retail constituted only 7 per cent of the total retail trade in 2011-12. However, it is estimated to grow at a Compounded Annual Growth Rate (CAGR) of 24 per cent and attain a 10.2 per cent share of total retail by 2016-17. The report further mentions that the overall retail market (organised and unorganised) is expected to grow at a CAGR of 15 per cent over the next 5 years 
from INR 23 trillion in 2011-12 to INR 47 trillion in 2016-17 and to USD 1.3 trillion by 2018 at a compounded annual growth rate of 10 per cent. $^{12}$ (N. Maruti Rao 2013) According to the report prepared by PricewaterhouseCoopers, the organised retail's growth rate is expected to reach 25 per cent by 2020. A report by Boston Consulting Group has published that the organised retail is estimated to be at USD 28 billion with 7 per cent penetration and is projected to be at USD 260 billion over the next decade with 21 per cent penetration.

Food and grocery constitutes 70 per cent of the Indian retail sector followed by apparel and fashion accessories. $^{4,15}$ (B. Kusuma, N. Durga Prasad, M. Srinivasa Rao 2013; Dr. Shahid Akhter, Iftekhar Equbal 2012) India is world's second largest producer of fruits and vegetables after Brazil and China. Although the agriculture sector has experienced several leaps of innovation and technological advancements, the food-processing sector is still in its nascent stage. Even with less than 4 per cent processing of fruits and vegetables, the Food-Processing sector in India is one of the largest in terms of production, export, consumption within India and growth prospects. The government has rendered it a high priority, with numerous incentives and fiscal reliefs, to encourage commercialisation and value addition to agricultural produce for minimising pre as well as post harvest wastage, generating export growth and employment. ${ }^{17}$ (Vijay Anand, Vikram Nambiar)

\subsection{Review of Literature}

According to a study conducted by Mukherjee and Patel (2005) the foreign retailing companies are working in close association with small manufacturers for in-house labels and are providing them high technologies like packaging technologies and bar coding. With the advent of these foreign retailers, sourcing from India has increased and they also bring in an efficient supply-chain management system. Joint ventures with international retailers are helping the Indian retail industry to get access to financial and global best practices. Besides, retailing being a non-negotiable service there is no possibility of improved efficiency through import competition and foreign direct investment is the way forward.

Chandu. K. L (2012) endeavors at outlining the government's policy on Foreign Direct Investment in retailing and attempts to analyse its pros and cons while examining the perceptions of the small retailers on the government's policy decision. He concludes that though the small shopkeepers are not so apprehensive about the big malls and stores, they oppose allowing FDI in retailing in India. This may be because they are not well conversant about the pros and cons of the proposed policy change. Thus, a countrywide discussion through the mass media is highly pertinent regarding this issue.

Dheerendra Kumar Baisla concludes in his study that foreign direct investment in retail will help integrate the Indian economy with the global economy. It will also provide more exposure to the organised retailing sector and result in availability of quality human resources at low costs. FDI in retail would decrease the intermediate costs, the costs of production and enforce setting up of integrated supply chains that would minimise wastage, give manufacturers a better price and will be beneficial to the producers as well as consumers.

Kamaladevi B. (2012) speaks about the global retailers' entry to India and their myths and realities. The study illustrates the status of organised food retailing in India with SWOT Analysis and highlights the farmers' issues towards FDI in multi-brand retailing. It also overviews the two faces of retail sector - challenges and key success factors and analyses the impact of organised retailing on the unorganised sector. Lastly, provides recommendations before allowing FDI in multi-brand 
retailing.

Vikram Singh (2013) studies the prospects of foreign direct investment in multi-brand retail in India. This paper, further, describes the concept of multi-brand retailing in India. It also gives an account of the present status of FDI in multi-brand retail in India and the advantages experienced by the various parties related to the retailing sector. Lastly, the paper overviews the two aspects of Indian retail sector - challenges and criticisms.

A. Vijaykumar (2014) in his paper captures the existing retail scenario in India and describes the limitations of the current scenario. The research paper discusses about opening up of the retail sector to foreign direct investment by the government and traces the efforts taken by the government regarding foreign direct investment in the retail sector. The paper also examines the reasons why foreign retailers are taking interest in India, the strategies they are adopting to enter India and their future in India. The current paper also focuses on the strategic issues and implications of FDI in Indian retailing and the major challenges that it faces.

\subsection{Research Objectives}

The government of India stated the rationale behind permitting FDI in the retail sector is that it ensures capital inflow into the country and fosters welfare of various sections of the society particularly traders, consumers and farmers. Apart from this allowing FDI in the retail sector enhances quality standard, employment opportunities, strengthens infrastructure, increases cost competitiveness, raises productivity, improves the supply chain technology along with better skills and expertise knowledge. The present research paper aims at:

- To study the working of food supply chain in the organised retail

- To analyse the benefits/flaws of the foreign direct investment in retail experienced by various stakeholders in the food supply chain

- To provide suitable recommendations/suggestions

\subsection{Research Methodology}

The research study is descriptive in nature, thus a descriptive research design is selected to achieve the above-mentioned objectives. The data is collected through the secondary sources like research reports, research papers, books, journals and websites. Primary data cannot be taken into consideration because it is a country wise report analysis. Preliminary work has been carried out as a literature review. Suitable analytical approach has been undertaken to complement the review of organized food retailing in India and how the various stakeholders (farmers, consumers, domestic organised retailers, local traders, government and real estate sector) dependent on retailing sector are affected by the introduction of foreign direct investment.

\section{Current FDI Policy}

Foreign direct investment is defined by the Reserve Bank of India as when a foreign country wants to establish any business operation in the domestic economy (India) which may include company under the company act, 1956 (joint venture or wholly owned subsidiary) or set up a liaison office or project office or a branch office of the foreign company which can undertake activities permitted under the foreign exchange management regulation, 2000. In simple words, it is a method of 
allowing financial resources, technology, management expertise and techniques in the diverse sectors of the economy. Basically it is considered as a tool to economic development.

Until 2011, the Indian Central Government did not allow Foreign Direct Investment (FDI) in multibrand retail. This prevented the foreign groups from any ownership in the convenience stores, supermarkets or other retail outlets. In late 2012, the Government of India introduced a Foreign Direct Investment policy, which allows foreign retailers to own up to $51 \%$ in multi-brand retail and $100 \%$ in single brand retail with certain pre-conditions.

\section{Organised Food Retailing in India}

With the total population of over a billion and the middle class population of over 300 millions, the organised retailing in India is still in its infancy. India has been slightly slow in joining the 'Organised Retail Revolution' that has rapidly transformed the economies in the other parts of the world. This is mainly due to the outstanding food retailing system established by the kirana or mom-and-pop stores that continue to meet all the retail requirements of the consumers without the convenience of shopping environment as provided by the retail chains and supermarkets; and also due to the highly disintegrated food supply chain which is enveloped with several intermediaries (from farmprocessor-distributor- retailer) leading to huge value loss and high costs.

This accompanied with lack of developed food processing industry has restrained the organised retail chains from leading the marketplace. The correction process is in progress and the systems are being established for the efficient Business-to-Business (farmer-processor, processor-retailer) solutions thus strengthening the core competencies of each player in the food supply chain. ${ }^{17}$ (Vijay Anand, Vikram Nambiar)

India is taking gigantic steps towards the Food Processing Industry with the emergence of the large private corporates, Government organisations and NGOs (Non-Government Organisations). These corporate companies and NGOs have reached out to the farmers and delivered them with assistance and timely advice in the remodeling of the farm practices with valuable feedbacks on different areas of farming from sowing to harvesting - comprising of manures, quality seed procurement, pesticides and fertilizers etc.

Few of the successful models that are excellent example are as follows:

- ITC's e-choupal model, which helps the soya bean farmers in contract producing for ITC for its commodity trading business.

- The PEPSI experimenting with Punjab farmers in growing the right quality of tomatoes for its tomato purees and pastes.

- In 1980 Mother's Dairy introduced vegetables and milk at the retail outlets in New Delhi. Later on Verka, Amul, Markfed followed the same concept and created cooperative societies for seeds, pulses, milk and milk products. This generated employment for many people. ${ }^{11}$ (Mathew Joseph, Nirupama Soundararajan, Manisha Gupta, Sanghmitra Sahu 2008)

These effective models are being replicated with necessary changes all over the country and the food retailing is getting integrated more strongly.

To counter the unmatched benefits of the mom-and-pop stores that is, convenient access and home delivery services, the organised retailers appear to have just one option - provide attractive prices to the consumers. And that would be possible for the large corporate retailers when they source products at the lowest possible prices. That would offer them a winning edge. For organised 
retailers, it all ultimately comes down to the ability of leveraging their scale to drive the merchandise costs down, increase the stock turns and avail better credit terms from their vendors. There are hidden and obvious areas where costs can be curtailed and the advantages of the lower cost of retailing can be passed on to the customers in the form of lower prices, which in turn should increase demand. One way of pruning costs is if the pressure points in the long, often redundant, supply chain for staples and produce can be identified and suitably dealt with. In India, the food supply chain is full of inadequacies - an outcome of ineffective infrastructure, numerous middlemen, complicated regulations and an indifferent attitude.

Conventionally in India, the supplier-retailer relation involved several levels such as the national distributor, the regional wholesaler and the end retailer. However this scenario is fast changing with the organised retail increasing its presence in the country where the relationship is directly with the manufacturer. However this new model has been affecting the relationships that the manufacturer enjoys with the traditional system that is still prevalent in the entire retail sector. The issue of differential pricing is being taken up at various forums and the manufacturers are addressing the growing dissatisfaction among the conventional retailers. However in the long term, the role of a national distributor would gradually fade away or get restricted to the rural regions only. With the advent of organised retail, the supplier-retailer relationship would be come under severe pressure, as each party would endeavor to squeeze maximum margins out of the other.

Retailing is a 'technology-intensive' industry. The key differentiator between the successful and not so successful retailers is largely in the area of technology. Moreover, it will be technology that will aid the organised retailers, providing both cost and service advantages. Successful retailers work closely with their vendors in order to predict consumer demand, shorten lead times, reduce inventory holding and thereby, save cost. The complicated information systems and processes, nowadays, help the retailers in achieving all these objectives. Most food retailers such as Food World have started tracking consumer purchases through Customer Relationship Management (CRM). The lifestyle retailers through their 'affinity clubs' and 'reward clubs' are establishing their processes.

\section{Beneficiaries of Foreign Direct Investment in Organised Food Retail}

\subsection{Farmers}

In India the agriculture sector, which is a major contributor to the economy, suffers with lack of transparency in prices, mandi norms and role of intermediaries. Intermediaries (i.e. middlemen) custom has been operational from the past decades due to which the farmers are not getting fair cost for their product; only $1 / 3$ of the consumer price goes to the farmer whereas $2 / 3$ goes to the middlemen and traders. This, in turn, increases the price to be paid by the consumers, as there is no direct interface between the farmer and retailer. Even most of the goods are lost or destroy due the ineffective supply chain, lack of storage facilities and logistic facilities. 20-25 per cent of the agroproducts get wasted due to improper storage facilities. ${ }^{7,18}$ (Dheerendra Kumar Baisla; Vikram Singh 2013)

Table No. 1: Profit margin of various stakeholders in the food supply chain

\begin{tabular}{|l|c|c|c|}
\hline $\begin{array}{l}\text { Supply Chain } \\
\text { Stakeholder }\end{array}$ & Price Break-up/kg & \% Share & Gross Margin \\
\hline Farmer & 27 & $28-30 \%$ & \\
\hline Transporter & 5 & $5-8 \%$ & $12-15 \%$ \\
\hline Commission Agent & 7 & $8-10 \%$ & $18-20 \%$ \\
\hline
\end{tabular}




\begin{tabular}{|l|c|c|c|}
\hline $\begin{array}{l}\text { Aggregator cum } \\
\text { Wholesaler }\end{array}$ & 11 & $12-13 \%$ & $20-25 \%$ \\
\hline Transporter & 5 & $5-8 \%$ & $8-10 \%$ \\
\hline Distributor* & 16 & $18-20 \%$ & $20-25 \%$ \\
\hline Retailer & 20 & $20-25 \%$ & $20-25 \%$ \\
\hline \multicolumn{2}{|c|}{} \\
\hline *In some cases sub-distributor also exist in the supply chain & \\
\hline
\end{tabular}

Source: Pratichee Kapoor \& Aneesh Saraiya, "Food Retailing: Backbone of Organized Retail Formats".

Table No. 2: Wastage of various food products

\begin{tabular}{|l|l|}
\hline Product & Wastage \\
\hline Tomatoes & $35 \%$ \\
\hline Mangoes & $30 \%$ \\
\hline Potatoes & $25 \%$ \\
\hline
\end{tabular}

Source: Vikeram Singh (2013), "FDI in multi-brand retail sector - A study regarding Indian context".

With the introduction of FDI in this sector, the farmers become the prime beneficiary as the foreign retailers would improve the upcoming the need for infrastructure, logistic, direct contact with retailers without middleman and also provide goods at cheaper prices to the consumers. The giant foreign retailers sell their products at very competitive prices. So as to achieve this objective, they would source the produce directly from the farmers, thereby, providing them with fair remuneration and removing intermediaries from the supply chain.

In India, the farmers still follow traditional practices of agriculture, which would change to horticulture farming due to modernisation of the entire supply chain with the entrance of foreign players. The agro-products grown are perishable in nature thus; they need efficient cold storage and transport facilities, which is very less at present. Allowing foreign direct investment can solve this problem, as it would raise funds for logistics as well as better transport facilities.

\subsection{Consumers}

The Indian consumers will experience the luxury of world-class shopping from the majestic malls to meet their daily life requirements. They will explore a new world of entertainment with food courts, multiplexes, games etc. while picking up consumer items to their greatest satisfaction. The consumers in the organised retail will have the opportunity to choose among a wide range of internationally famous brands with huge space for product display, pleasant shopping environment, better customer care and maintenance of hygiene. The entry of foreign players will also increase the market competition resulting in reduced prices to the consumers. The consumer will be the 'king' in true sense as the bargaining power will be in their hands.

\subsection{Domestic Organised Retailers}

The major benefit of the entry of foreign companies $\square$ into the organised retail sector is the enhanced flow of investments in overall infrastructure and the establishment of new supply chains. Foreign Direct Investment in retailing would provide an opportunity for the cash deficient domestic retailers to bridge the gap between capital required and raised. FDI also brings in knowledge of processes, management and technology. Beyond capital, the Indian retail industry requires global integration. Through global integration, the domestic organised retailers would get to understand various key strategies to compete globally. Also, the global integration can potentially open avenues of export markets for the Indian farmers and manufacturers. $\square$ Foreign Direct Investment in the domestic 
companies, moreover, provides assured product quality, a better supply chain and exposure to a wider variety of products.

\subsection{Local Small Traders}

The big-box foreign retailers will boost competition in the market pressurising the local small traders and retailers to improve their logistics, supply chain and display system. These traders would get an exposure to global trade and practices. They would be forced to change their age-old methods, systems and operations and learn the modern way of business. With this, the consumers would be benefitted eventually in the long run.

\subsection{Real Estate Sector}

Retail is closely dependent on the real estate sector, as any retailer would require substantial space for establishing business. The decision to allow 51\% FDI in multi-brand retail is expected to motivate the realtors to revive their plans to build malls and shopping complexes, which were postponed in the past few years due to economic slowdown. Thus, the real estate sector in India would go through a revamp due to the demand for high-end retail malls and the changing perception of the people towards an enjoyable shopping experience. The real estate companies would receive more opportunities with the opening up of FDI in multi-brand retail.

\subsection{Government}

Indian economy needs trillions of dollars to build the necessary infrastructure, housing, schools and hospitals for its growing population. Indian economy is small, with limited surplus capital. Indian government is already operating on budget deficits. It is just not possible for the Indian government or the Indian investors to deliver funds for this expansion, employment generation and growth at the rate India needs. Foreign direct investment in the organised retail sector would increase tax revenues of the government thereby solving the funding issues. ${ }^{1}$ (A. Vijaykumar 2014)

Actually, foreign direct investment is one of the important sources of investments for a developing economy like India wherein it expects investments from the multinational companies to improve the countries growth rate, create jobs, share their expertise, back - end infrastructure and research and development in the host countries.

\section{Concerns Regarding Foreign Direct Investment in Organised Retail}

There are certain apprehensions attached to the government's decision to allow foreign direct investment in retail sector. These concerns/fears are discussed below:

\subsection{Dominance of Organised Retailers}

The local mom-and-pop stores, small shopkeepers, hawkers, peddlers, etc. still form major section of the Indian Economy. FDI in single-brand and multi-brand retail would fortify the organised retail in the country. These organised retailers may tend to dominate the entire consumer market. It may lead to unfair competition and ultimately result in the large-scale exit of the small traders, especially the family managed outlets (local " mom and pop" stores would be compelled to shut down). ${ }^{14}$ (Richa Arora, Supriya Mathew, Anupama Suresh 2014) The local traders in the vicinity of the big domestic retailers might find it difficult to compete. It would jeopardise the market position of unorganised retail sector and would adversely affect the small retailers, farmers and consumers. Furthermore, this would give rise to monopolies of large corporate houses, which can adversely affect the pricing and availability of goods. 


\subsection{Lead to Unemployment}

The modernisation and automation (use of capital-intensive techniques) of the operations, processes and systems by the foreign retailers would reduce job opportunities and create unemployment. The work culture of global retailers is quite different from those of Indian players. They believe in earning profits by cutting costs as much as possible and at the same time are conscious towards career of their employees. Their approach is more oriented towards achieving ends rather than means. They would create job opportunities only for skilled and educated people but a large number of semi-skilled workers currently engaged in the retail industry would be rendered jobless. The direct connection of the retailers with the suppliers and manufacturers would remove intermediaries from the supply chain and result in loss of jobs for the middlemen. ${ }^{9}$ (Dr. Gaurav Aggarwal, Faisal Noman 2013)

\subsection{Rise in Real Estate Cost}

It is quite evident that the foreign retailers desiring to open up their stores and malls would certainly look for places in the heart of the cities. There shall be a war for space, initiated among such companies. It will lead to increase in the cost of real estate in the cities that will eventually affect the interests of the ordinary people who aspire to have their own house within the limit of the cities.

\subsection{Exploitation of Consumers}

It is debated that the consumers shall benefit in the form of wide-variety, quality and availability of quality merchandise. However, it is feared that in the long run, consumers may have to face the risk of higher prices, substandard quality and limited options once these big foreign retailers settle down comfortably in the Indian market. ${ }^{1}$ (A. Vijaykumar 2014)

\section{Policy Suggestions}

The government policy to allow foreign direct investment in single-brand and multi-brand retail is not free from flaws. There are certain weak areas in the policy but if proper steps are implemented towards the same, these minor issues can be easily sorted out. The following suggestions are made for the improvement:

- A distinctive legal and regulatory framework should be constituted to ensure protection of small retailers against exploitation, dislocation by unfair means and predatory pricing by large foreign retailers.

- The entry of foreign retailers must be gradual and in a phased manner with social safeguards so as to minimise the effects of labour dislocation.

- A business association or national commission for retailers, suppliers and consumers should also be established to safeguard the interests of local businessmen such as prohibit the international retailers from buying products below cost and selling below cost, provide support to small manufacturers/traditional retailers and launch multi-stakeholder initiatives in the supermarket chains.

- Development of the traditional retail markets through public-private partnership.

- Proper attention should be paid to staff recruitment, procuring, market competition, retail formats and investments in cold storage and warehouse facilities so that not only does the capital flows in but also it is optimally invested for the welfare of the domestic retailers as well as " mom and pop stores" which account for 70 per cent of the total retail business.

- In order to maintain fair competition between the large foreign supermarkets and local retail 
stores, zoning laws should be executed.

- The foreign retailers have access to international financial institutions offering loans at lowinterest rates. Availability of institutional credit, at lower rates, by the public sector banks, to assist the small traders in upgrading and improving efficiencies, would provide a levelplaying field.

- Encourage the farmers to form co-operative societies to sell their produce directly to organised retailers $\square$ similar to the Mother Dairy Model.

- Stringent regulations to be made against collusion and predatory pricing. Additionally, a code of conduct to be drafted for the organised retail sector for dealing with their suppliers.

\section{Conclusion}

The foreign direct investment in retail would lead to establishment of well integrated and sophisticated supply chain, effective transportation management, inflow of latest technical knowhow, availability of standard and latest products, increased sourcing from India and upgradation of human skills. So there is no doubt about the fact that the advantages of foreign direct investment outweigh its disadvantages. But the Indian government must be watchful about the fears raised by the various critics and adequate precautions must be taken so that the traditional retailers coexist with the big-box foreign retailers.

In the present time of fierce competition and a quest to achieve significant level of economic development, liberalisation of economic policies in order to attract foreign direct investment is the need of the hour. India is a lucrative market and its integration with the global markets would only add to its potential. It has emerged as one of the prime destinations for the investment of funds from an impressive number of foreign investors. India should embrace this new era of retailing and the government should form the right kind of bodies to vigil these giant retailers.

\section{Acknowledgements}

The research work is fully funded by the University Grants Commission of India [UGC-Ref. No. 1853/(NET-June 2012)] to the author. I thank Dr. Manjula Jain and Dr. Swatantra Kumar Singh for the research assistance. All views and remaining errors are mine. The usual disclaimer applies.

Notes

1. The ITC staff offers free inputs on the latest trends in the preparation of crops and agricultural practices to the farmers. Thus, adapting the best practices at a primary stage ensures growth in the yield for farmers and also allows ITC to meet the quality parameters in a time-efficient manner. The farmer is completely free to sell his produce either to ITC or the Agricultural Produce Marketing Committee (APMC) markets.

2. Mother Dairy was established in 1974 with a view of making liquid milk available to the urban consumers. It was set up by National Dairy Development Board under first phase of operation flood programme. It markets dairy products such as ice cream, dahi, lassi, butter, cheese, dairy whitener, Dhara range of edible oils, Safal of fresh fruits and vegetables, frozen fruits and vegetables and fruit juices. It follows cooperative models where it directs the formation of federation, with the help of village-level societies and district-level unions, whose prime responsibility is marketing of milk and milk products. At present, Mother Dairy operates 170 milk producers unions and 15 state federations for milk marketing. It ensures that the farmers get fair market price by offering quality produce and also provides the produce to the consumers at reasonable prices through minimising costs.

References

1. A. Vijaykumar (2014), "FDI in Indian Retail Sector: Strategic Issues and Implications", International Journal of Management and Sustainability, Vol. 3, No. 2, pp. 24-41. 
2. Aditya P. Tripathi, "Emerging Trends in Modern Retail Formats \& Customer Shopping Behavior in Indian Scenario: A Meta Analysis \& Review", pp. 1-26.

3. Arpita Mukherjee \& Nitisha Patel (2005), "FDI in Retail Sector: India", Academic Foundation in association with ICRIER and Ministry of Consumer Affairs, Food and Public Distribution (Govt. of India).

4. B. Kusuma, N. Durga Prasad, M. Srinivasa Rao (2013), "A Study on Organized Retailing and its Challenges and Retail Customer Services”, Innovative Journal of Business and Management, Vol. 2, Issue 5, SeptemberOctober, pp. 97-102.

5. Chandu K. L. (2012), "The New FDI policy in Retail in India: Promises, Problems and Perceptions", Asian Journal of Management Research, Vol. 3, Issue 1, ISSN: 2229-3795, pp. 100-106.

6. Corporate Catalyst (India) Pvt. Ltd. (2015), "A Brief Report on Retail Sector in India”, January, www.cci.in, accessed on $27^{\text {th }}$ January 2016.

7. Dheerendra Kumar Baisla, "Foreign Direct Investment in Indian Retail Sector: Current Position, Impact and Challenges", International Journal of Legal Developments and Allied Issues, Vol. 2, Issue 4, ISSN: 2454-1273, pp. 54-71.

8. "FDI in Multi Brand Retailing: The Reality Check", Discussion Paper Towards fulfillment of internship with CUTS-CCIER, February-March, 2014, pp. 1-21.

9. Dr. Gaurav Aggarwal and Faisal Noman (2013), "Foreign Direct Investment (FDI) in Indian Retail Sector", International Journal of Management Research and Review, Vol. 3, Issue 8, August, Article No. 19, ISSN 22497196, pp. 3342-3352.

10. Kamaladevi B (2012), "FDI in India’s Multi Brand Retail - Boon or Bane", Universal Journal of Management and Social Sciences, Vol. 2, No. 1, January, pp. 1-16.

11. Mathew Joseph, Nirupama Soundararajan, Manisha Gupta and Sanghmitra Sahu (2008), "Impact of Organized Retailing on the Unorganized Sector", Report by Indian Council for Research on International Economic Relations (ICRIER), May 2008.

12. N. Maruti Rao (2013), "FDI in multi-brand retailing - challenges and opportunities", Elixir International Business Management, 59A, ISSN: 2229-712X, pp. 15611-15617.

13. RGNUL-IPAN Working Paper Series (2012), "Foreign Direct Investment in Multi-Brand Retail in India", IPAN Working Paper No. 01/2012, Rajiv Gandhi National University of Law, Punjab.

14. Richa Arora, Supriya Mathew and Anupama Suresh (2014), "Impact of FDI on Indian Retail Sector: Challenges and Opportunities", Annual Research Journal of Symbiosis Centre for Management Studies, Pune, Vol. 1, January 2013- January 2014, ISSN: 2348-0661, pp. 137-151.

15. Dr. Shahid Akhter; Iftekhar Equbal (2012), "Organized Retailing in India - Challenges and Opportunities", International Journal of Multidisciplinary Research, Vol. 2, Issue 1, January, ISSN 2231-5780, pp. $281-291$.

16. Subhadip Mukherjee (2011), "Policies of retail sector of India and other selected countries", UTMS Journal of Economics, Vol. 2, Issue 2, pp. 171-180.

17. Vijay Anand and Vikram Nambiar, "Indian Food Retail Sector in the Global Scenario".

18. Vikram Singh (2013), "FDI in Multi-brand Retail Sector: A Study Regarding Indian Context", Asia Pacific Journal of Marketing and Management Review, Vol. 2, Issue 7, July, ISSN: 2319-2836, pp. 121-131. 